\title{
Novel catalytic synthesis of 6,7-dimethoxyisatin with the use of heteropolyacids (HPAs) as acid solid catalyst
}

\author{
Ali Gharib ${ }^{1,2, *}$, Mohsen Daneshtalab ${ }^{3}$, J. (Hans) W. Scheeren ${ }^{4}$, Fatemeh. F. Bamoharram ${ }^{1}$, \\ Mina Roshani ${ }^{1}$, Manouchehr Jahangir ${ }^{1}$ \\ ${ }^{1}$ Department of Chemistry, School of Science, Islamic Azad University, Mashhad, IRAN \\ ${ }^{2}$ Agricultural Researches and Services Center, Mashhad, IRAN \\ 3 School of Pharmacy, Memorial University of Newfoundland, St. John's, Newfoundland, Canada A1C 3V6 \\ ${ }^{4}$ Cluster for Molecular Chemistry, Department of Organic Chemistry, Radboud University Nijmegen, The Netherlands \\ *Corresponding author: aligharib5@yahoo.com
}

\begin{abstract}
An efficient method for the preparation of 6,7-dimethoxyisatin and its derivatives was developed with good yield by using Preyssler-type heteropolyacid (HPA) as acid catalyst under green conditions. The comparison between Keggin type heteropolyacids, $\mathrm{H}_{3}\left[\mathrm{PW}_{12} \mathrm{O}_{40}\right], \mathrm{H}_{4}\left[\mathrm{SiW}_{12} \mathrm{O}_{40}\right]$ and $\mathrm{H}_{4}\left[\mathrm{SiMo}_{12} \mathrm{O}_{40}\right], \mathrm{H}_{3}\left[\mathrm{PMo}_{12} \mathrm{O}_{40}\right]$ and mineral acids with Preyssler's anion shows that the latter possess better catalytical activity than the other heteropolyacids and no degradation of the structure was observed.
\end{abstract}

Keywords: Heteropolyacid, catalyst, Preyssler, Isatin, mandelonitrile.

\section{INTRODUCTION}

The problems associated with handling and disposal of inorganic acids, and their environmental and potential hazards have raised our interest in the development of alternative procedures using solid acid catalysts ${ }^{1}$. Due to their super-acidic properties, heteropolyacids, HPAs, can be used in the reactions requiring electrophilic catalysis. Heteropolyacids (HPAs) are applied both in bulk or supported forms, with homogeneous and heterogeneous catalysis being possible. Heteroplyacids (HPAs) have many advantages that make them environmentally attractive in the academic, industrial and economical signification. These are useful acids and oxidation catalysts in various reactions since their catalytic features can be varied at a molecular level ${ }^{2}$. Among them, the Keggin-type, HPAs have long been known to be good catalysts for oxidation reactions ${ }^{3}$. They exhibit great advantages: for example, their catalytic properties can be tuned by changing the identity of the charge-compensating counter cations, heteroatoms and framework metal atoms ${ }^{3}$. Isatins $(1 \mathrm{H}-$ indole-2, 3-dione), synthetically versatile substrates, can be used for the synthesis of a large variety of heterocyclic compounds, such as indoles and quinolines, and as raw material for drug synthesis. Isatins have also been found in mammalian tissue and their function as a modulator of biochemical processes has been the subject of several discussions.

The advances in the use of isatins for organic synthesis during the last twenty-five years, as well as a survey of

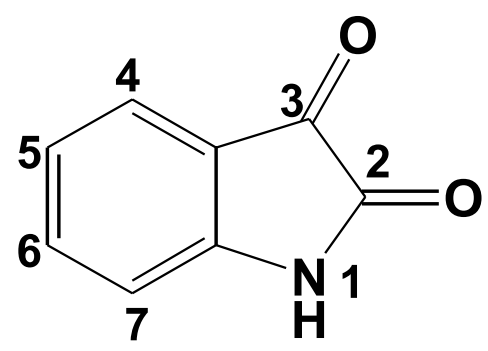

Figure 1. Isatin (1H-indole-2, 3-dione) their biological and pharmacological properties are reported in this review and in the accompanying supplementary information. Isatin $(1 \mathrm{H}$-indole-2, 3-dione, Figure 1) was first obtained by Erdman and Laurent in 1841 as a product from the oxidation of indigo by nitric and chromic acids. The synthetic versatility of isatin has led to the extensive use of this compound in organic synthesis.

Isatin (2, 3-dioxindole) is an endogenous compound with a long history and a wide range of pharmacological effects. Isatins are synthetically versatile substrates. They can be used for the synthesis of a large variety of heterocyclic compounds such as indoles and quinolines. They also display diverse pharmacological activities ${ }^{4}$. In nature, isatin and its derivatives were found in various plants ${ }^{5,6}$. Therefore, the synthesis of isatins is of great importance and interest. In literature ${ }^{4}$ there were some reports about synthesizing of isatins. The three methods of synthesizing 6, 7-dimethoxyisatin 3 from 2, 3dimethoxyaniline are as follows: I) Stolle procedure: Aniline reacted with oxalyl chloride only gave product 3 with a very poor yield ${ }^{5}$. II) Sandmeyer methodology: it is the oldest and the most frequently used method for the synthesis of isatins ${ }^{7}$. III) Martinet procedure: condensation of aniline and diethylketomalonate gave mainly oxindole, which was treated with sodium hydroxide solution and oxygen to give isatin $3^{8}$. The first step in this method, also gave other two by-products. Also, aniline was treated with chloral hydrate to give isatin $\mathbf{2}$ in poor yield. There are two other methods of synthesizing $\mathbf{3}$ from the same substance ${ }^{4}$ nitroveratraldehyde ${ }^{8}$.

But these methods were both more complex and with poor yields.

\section{EXPERIMENTAL SECTION}

\section{Materials \& Instruments}

All chemical compounds were purchased commercially. IR spectra were obtained on a Buck 500 scientific spectrometer. Melting points were uncorrected. The ${ }^{1} \mathrm{H}$ NMR spectra in $\mathrm{CDCl}_{3}$ with TMS as the internal standard 
were recorded on a FT NMR Bruker $100 \mathrm{MHz}$ Aspect 3000 spectrometer.

Preparation of supported Preyssler catalyst $\mathrm{H}_{14}\left[\mathrm{NaP}_{5} \mathrm{~W}_{29} \mathrm{MoO}_{110}\right]$

This catalyst is provided in accordance with the literature?.

General procedure, Synthesis of 2-nitro-3, 4-dimethoxy mandelonitrile (2) and its derivatives:

2-nitroveratraldehyde or other aldehydes (10 mmol) was added to the solution of $\mathrm{NaHSO}_{3}(11 \mathrm{mmol})$ and water $(12 \mathrm{~mL})$, then the mixture was heated to $50^{\circ} \mathrm{C}$, when 2-nitroveratraldehyde was dissolved; it was cooled to $0^{\circ} \mathrm{C}$ by ice bath, the solution of $\mathrm{KCN}(20 \mathrm{mmol})$ and water $(5$ $\mathrm{mL}$ ) was added dropwise, and stirred for 2 hours at $0^{\circ} \mathrm{C}$.

Then, heteropolyacids catalysts $(0.06 \mathrm{mmol})$ was added to the reaction mixture and then, stirred for $2 \mathrm{hrs}$ at $0^{\circ} \mathrm{C}$ (ice bath) again. The progress of the reaction was monitored by TLC. After the completion of the reaction, the mixture was filtered to separate the catalyst, and was extracted with diethyl ether. The extract was washed with water and then dried $\left(\mathrm{MgSO}_{4}\right)$.

The solvent was evaporated and the residue was purified by recrystalization from $\mathrm{CHCl}_{3}$ and white crystals 2 was obtained.

Synthesis of 6, 7-dimethoxyisatin (3) and its derivatives (4-9):

A solution of 2-nitro-3, 4-dimethoxy mandelonitrile (3 $\mathrm{mmol})$ and glacial acetic acid $(5 \mathrm{~mL})$, was treated with heteropolyacids catalysts $(0.06 \mathrm{mmol})$. The mixture was heated to $50^{\circ} \mathrm{C}$ and then stirred for 2 hours. $\mathrm{NaBH}_{4}(20$ $\mathrm{mg}, 2 \mathrm{mmol}, 1$ equiv) was added and the mixture was stirred for additional 30 minutes. The progress of the reaction was monitored by TLC. After the completion of the reaction, the mixture was filtered to separate the catalyst, then, the mixture was diluted with water $(8 \mathrm{~mL})$. The orange solution was extracted with chloroform and the extract was washed with water and then dried $\left(\mathrm{MgSO}_{4}\right)$. The solvent was evaporated, leaving the yellow solid of isatin. Recrystallization was carried out with toluene and gave yellow crystals $\mathbf{3}$.

\section{RESULTS AND DISCUSSION}

We reported our researches about the synthesis of isatins compounds and therefore using heteropolyacids catalysts and 2-nitro-3, 4-dimethoxy mandelonitrile 2 under the mild conditions (Scheme 1).

For the preparation of 6, 7-dimethoxyisatin 3, 2-nitro3, 4-dimethoxy mandelonitrile 2 , acetic acid and $\mathrm{H}_{14}$
$\left[\mathrm{NaP}_{5} \mathrm{~W}_{29} \mathrm{MoO}_{110}\right]$, or various heteropolyacids as the catalyst are used. The results were compared with the yields of other catalysts types (Table 2). The results for the products in withdrawing groups have lower yields than the products of donating electron groups (Table 1, entries 6 $-8,3)$. With the use of $\mathrm{H}_{14}\left[\mathrm{NaP}_{5} \mathrm{~W}_{29} \mathrm{MoO}_{110}\right]$ as the catalyst in the synthesis of isatin derivatives, the high yields $96 \%$ and $93 \%$ for products 2 and 3 were obtained (Table 1, entries 1, 2).

When, $\mathrm{H}_{3} \mathrm{PMo}_{12} \mathrm{O}_{40}$ was used in the reaction, the yields for $\mathbf{2}$ and $\mathbf{3}$ were $86 \%$ and $90 \%$, but the yields were lower when using $\mathrm{HCl}, \mathrm{H}_{2} \mathrm{SO}_{4}$ and $\mathrm{HY}$-Zeolite (Table 2, entries $5-7)$.

The yields of the products $\mathbf{1}, \mathbf{2}$ were good by using other heteropolyacids (Table 2, entries $1-4$ ).

The physical data for compounds $(2-9)$ such as ${ }^{1} \mathrm{H}$ NMR, IR, and melting points were shown in Table 3.

Table 1. The yields of products $(2-9)$ using $\mathrm{H}_{14}\left[\mathrm{NaP}_{5} \mathrm{~W}_{29} \mathrm{MoO}_{110}\right]$

\begin{tabular}{|c|c|c|}
\hline Entry & Compound & ${ }^{a}$ Yield $(\%)$ \\
\hline 1 & 2-nitro-3,4-dimethoxy mandelonitrile(2) & 96 \\
\hline 2 & 6,7-dimethoxyisatin(3) & 93 \\
\hline 3 & 6,7-dimethoxy-8-methylisatin (4) & 91.5 \\
\hline 4 & 6,7-dimethoxy-8-ethylisatin (5) & 90 \\
\hline 5 & 6,7-dimethoxy-8-ethoxylisatin (6) & 90.5 \\
\hline 6 & 6,7-dimethoxy-8-chloromethylisatin (7) & 84.5 \\
\hline 7 & 6,7-dimethoxy-8-bromomethylisatin (8) & 86 \\
\hline 8 & 6,7-dimethoxy-8-phenylisatin (9) & 87.5 \\
\hline
\end{tabular}

Table 2. The yields of products 2 and 3 using different catalysts

\begin{tabular}{|l|l|c|c|}
\hline Entry & Catalyst & ${ }^{a}$ Yield 2(\%) & ${ }^{a}$ Yield 3(\%) \\
\hline 1 & $\mathrm{H}_{3}\left[\mathrm{PW}_{12} \mathrm{O}_{40}\right]$ & 80.5 & 78 \\
\hline 2 & $\mathrm{H}_{4}\left[\mathrm{SiW}_{12} \mathrm{O}_{40}\right]$ & 81.5 & 80 \\
\hline 3 & $\mathrm{H}_{4}\left[\mathrm{SiMo}_{12} \mathrm{O}_{40}\right]$ & 84 & 79.5 \\
\hline 4 & $\mathrm{H}_{3}\left[\mathrm{PMo}_{12} \mathrm{O}_{40}\right]$ & 86 & 90 \\
\hline 5 & $\mathrm{HCl}$ & 62 & 66.5 \\
\hline 6 & $\mathrm{HY}-\mathrm{Zeolite}_{7}$ & 70 & 70 \\
\hline 7 & $\mathrm{H}_{2} \mathrm{SO}_{4}$ & 72 & 70 \\
\hline
\end{tabular}

${ }^{\mathrm{a}}$ Isolated yields.

\section{Conclusion}

In conclusion, we obtained a good method for the synthesis of Isatins, under mild, clean, green conditions. Heteropolyacids (HPAs) are solid acid and super acids; they were used as acid and oxidative catalysts in this synthesis. Heteropolyacids are recycled and reused in the<smiles>[R]c1cc(C=O)c([N+](=O)[O-])c(OC)c1OC</smiles>

(1)<smiles>[R]c1cc(C(O)C#N)c([N+](=O)[O-])c(OC)c1OC</smiles>

(2)<smiles>[R]c1cc2c(c(OC)c1OC)NC(=O)C2=O</smiles>

(3)

$\mathrm{R}=\mathrm{H}, \mathrm{CH}_{3}, \mathrm{Cl}, \mathrm{Br}, \mathrm{C}_{2} \mathrm{H}_{5}, \mathrm{C}_{2} \mathrm{H}_{5} \mathrm{O}, \mathrm{Ph}$

Scheme 1. Synthesis of isatin compounds 
Table 3. Spectral data $(2-9)$

\begin{tabular}{|c|c|c|c|c|}
\hline Entry & Compound & ${ }^{1} \mathrm{HNMR} \delta(\mathrm{ppm}) \mathrm{CDCl}_{3}$ (Solvent) & IR Vmax $\mathrm{cm}^{-1}(\mathrm{KBr}$ Plette $)$ & $\mathrm{Mp} /{ }^{\circ} \mathrm{C}$ \\
\hline 1 & $\begin{array}{l}\text { 2-nitro-3,4-dimethoxy } \\
\text { mandelonitrile(2) }\end{array}$ & $\begin{array}{l}3.3(\mathrm{br}, 1 \mathrm{H}, \mathrm{OH}), 3.959\left(\mathrm{~s}, 3 \mathrm{H}, \mathrm{OCH}_{3}\right) \\
3.962\left(\mathrm{~s}, 3 \mathrm{H}, \mathrm{OCH}_{3}\right), 5.664(\mathrm{~s}, 1 \mathrm{H}, \\
\mathrm{CHCN}), 7.07(\mathrm{~d}, 1 \mathrm{H}, \mathrm{J}=8.04 \mathrm{~Hz}, \mathrm{Ar}-\mathrm{H}) \\
7.39(\mathrm{~d}, 1 \mathrm{H}, \mathrm{J}=8.04 \mathrm{~Hz}, \mathrm{Ar}-\mathrm{H})\end{array}$ & $3414(\mathrm{OH}), 2250(\mathrm{CN})$ & $89-90$ \\
\hline 2 & 6,7-dimethoxyisatin(3) & $\begin{array}{l}3.90\left(\mathrm{~s}, 3 \mathrm{H}, \mathrm{OCH}_{3}\right), 3.95\left(\mathrm{~s}, 3 \mathrm{H}, \mathrm{OCH}_{3}\right) \\
6.64(\mathrm{~d}, 1 \mathrm{H}, \mathrm{J}=8.4 \mathrm{~Hz}, \mathrm{Ar}-\mathrm{H}), 7.40(\mathrm{~d}, 1 \mathrm{H}, \\
\mathrm{J}=8.04 \mathrm{~Hz}, \mathrm{Ar}-\mathrm{H}), 7.72(\mathrm{br}, 1 \mathrm{H}, \mathrm{NH})\end{array}$ & $3229,1753,1703,1626$ & $\begin{array}{l}\text { 208-211, lit(209- } \\
210)[6]\end{array}$ \\
\hline 3 & $\begin{array}{l}\text { 6,7-dimethoxy-8-methylisatin } \\
\text { (4) }\end{array}$ & $\begin{array}{l}3.93\left(\mathrm{~s}, 3 \mathrm{H}, \mathrm{OCH}_{3}\right), 4.02\left(\mathrm{~s}, 3 \mathrm{H}, \mathrm{OCH}_{3}\right) \\
1.5\left(\mathrm{~s}, 3 \mathrm{H}, \mathrm{CH}_{3}\right), 6.71(\mathrm{~d}, 1 \mathrm{H}, \mathrm{J}=7.8 \mathrm{~Hz} \\
\text { Ar- } \mathrm{H}), 7.20(\mathrm{~d}, 1 \mathrm{H}, \mathrm{J}=7.8 \mathrm{~Hz}, \mathrm{Ar}-\mathrm{H}) \\
7.81(\mathrm{br}, 1 \mathrm{H}, \mathrm{NH})\end{array}$ & $\begin{array}{l}3236,1761,1739,1639 \\
1214\end{array}$ & $218-221$ \\
\hline 4 & 6,7-dimethoxy-8-ethylisatin (5) & $\begin{array}{l}3.88\left(\mathrm{~s}, 3 \mathrm{H}, \mathrm{OCH}_{3}\right), 3.97\left(\mathrm{~s}, 3 \mathrm{H}, \mathrm{OCH}_{3}\right) \\
1.62\left(\mathrm{~s}, 3 \mathrm{H}, \mathrm{CH}_{3}\right), 6.98(\mathrm{~d}, 1 \mathrm{H}, \mathrm{J}=8.5 \mathrm{~Hz}, \\
\mathrm{Ar}-\mathrm{H}), 7.21(\mathrm{~d}, 1 \mathrm{H}, \mathrm{J}=8.5 \mathrm{~Hz}, \mathrm{Ar}-\mathrm{H}) \\
7.86(\mathrm{br}, 1 \mathrm{H}, \mathrm{NH})\end{array}$ & $\begin{array}{l}3244,1767,1745,1638 \\
1216\end{array}$ & $220-222$ \\
\hline 5 & $\begin{array}{l}\text { 6,7-dimethoxy-8-ethoxylisatin } \\
\text { (6) }\end{array}$ & $\begin{array}{l}3.98\left(\mathrm{~s}, 3 \mathrm{H}, \mathrm{OCH}_{3}\right), 4.02\left(\mathrm{~s}, 3 \mathrm{H}, \mathrm{OCH}_{3}\right) \\
1.82\left(\mathrm{~s}, 2 \mathrm{H}, \mathrm{OC}_{2} \mathrm{H}_{5}\right), 7.2(\mathrm{~d}, 1 \mathrm{H}, \mathrm{J}= \\
8.0 \mathrm{~Hz}, \mathrm{Ar}-\mathrm{H}), 7.34(\mathrm{~d}, 1 \mathrm{H}, \mathrm{J}=8.0 \mathrm{~Hz}, \mathrm{Ar}- \\
\mathrm{H}), 7.89(\mathrm{br}, 1 \mathrm{H}, \mathrm{NH})\end{array}$ & $\begin{array}{l}3247,1775,1764,1645 \\
1220\end{array}$ & $226-227$ \\
\hline 6 & $\begin{array}{l}\text { 6,7-dimethoxy-8- } \\
\text { chloromethylisatin (7) }\end{array}$ & $\begin{array}{l}3.96\left(\mathrm{~s}, 3 \mathrm{H}, \mathrm{OCH}_{3}\right), 4.06\left(\mathrm{~s}, 3 \mathrm{H}, \mathrm{OCH}_{3}\right) \\
3.82\left(\mathrm{~s}, 2 \mathrm{H}, \mathrm{ClCH}_{2}\right), 7.51(\mathrm{~d}, 1 \mathrm{H}, \mathrm{J}= \\
8.1 \mathrm{~Hz}, \mathrm{Ar}-\mathrm{H}), 7.68(\mathrm{~d}, 1 \mathrm{H}, \mathrm{J}=8.1 \mathrm{~Hz}, \mathrm{Ar}- \\
\mathrm{H}), 7.93(\mathrm{br}, 1 \mathrm{H}, \mathrm{NH})\end{array}$ & $\begin{array}{l}3249,1785,1773,1635 \\
1239,754\end{array}$ & $245-247$ \\
\hline 7 & $\begin{array}{l}\text { 6,7-dimethoxy-8- } \\
\text { bromomethylisatin (8) }\end{array}$ & $\begin{array}{l}3.74\left(\mathrm{~s}, 3 \mathrm{H}, \mathrm{OCH}_{3}\right), 4.06\left(\mathrm{~s}, 3 \mathrm{H}, \mathrm{OCH}_{3}\right) \\
2.91\left(\mathrm{~s}, 2 \mathrm{H}, \mathrm{BrCH}_{2}\right), 7.33(\mathrm{~d}, 1 \mathrm{H}, \mathrm{J}= \\
7.3 \mathrm{~Hz}, \mathrm{Ar}-\mathrm{H}), 7.52(\mathrm{~d}, 1 \mathrm{H}, \mathrm{J}=7.3 \mathrm{~Hz}, \mathrm{Ar}- \\
\mathrm{H}), 7.72(\mathrm{br}, 1 \mathrm{H}, \mathrm{NH})\end{array}$ & $\begin{array}{l}3231,1722,1756,1625 \\
1224,680\end{array}$ & $252-253$ \\
\hline 8 & $\begin{array}{l}\text { 6,7-dimethoxy-8-phenylisatin } \\
\text { (9) }\end{array}$ & $\begin{array}{l}3.89\left(\mathrm{~s}, 3 \mathrm{H}, \mathrm{OCH}_{3}\right), 4.25\left(\mathrm{~s}, 3 \mathrm{H}, \mathrm{OCH}_{3}\right) \\
7.65(\mathrm{~d}, 5 \mathrm{H}, \mathrm{J}=7.6 \mathrm{~Hz}, \mathrm{Ar}), 7.36(\mathrm{~d}, 1 \mathrm{H}, \mathrm{J} \\
=8.5 \mathrm{~Hz}, \mathrm{Ar}-\mathrm{H}), 7.46(\mathrm{~d}, 1 \mathrm{H}, \mathrm{J}=8.5 \mathrm{~Hz}, \\
\text { Ar-H), } 7.78(\mathrm{br}, 1 \mathrm{H}, \mathrm{NH})\end{array}$ & $\begin{array}{l}3130,3120,1689,1731 \\
1612,1215\end{array}$ & $244-245$ \\
\hline
\end{tabular}

reaction very easily and without the loss of the catalytic activities. These catalysts are involved with organic compounds in the reaction mixture and filtered very easily; they are non-corrosive, non-poisonous, inexpensive, ecofriendly and environment friendly.

\section{Acknowledgement}

The authors are thankful to Chemistry Department, Islamic Azad University of Mashhad and Agricultural Researches \& Services Center, Mashhad, Feyzabad, Iran, Chemistry Department, University of Oslo, Norway for support of this work and with special thanks from Professor. Dr. Mohsen Daneshtalab from School of Pharmacy, Memorial University of Newfoundland, St. John's, Newfoundland, Canada and Professor. Dr. J. (Hans) W. Scheeren from Organic Chemistry Department, Radboud University Nijmegen, The Netherlands.

\section{LITERATURE CITED}

1. Romanelli, G., Autino J. C., Baronetti, G. \& Thomas, H. (2001). H. Efficient Deprotection of Phenol Methoxymethyl Ethers Using a Solid Acid Catalyst with WellsDawson Structure. Molecules. 6, 1006 - 1011. DOI:10.3390/ 61201006.

2. Okuhara, T., Mizuno, N. \& Misono, M. (1996). Advances in Catalysis. Catalytic Chemistry of Heteropoly compounds. $41,113-252$.

3. Kozhevnikov, I. V.(1987). Advances in catalysis by heteropoly acids. Advances in catalysis by heteropoly acids. Russ. Chem. Rev. 56(9), 811 - 825. DOI: 10.1070/RC1987v056n09ABEH003304.

4. Joaquim, F. M., Simon, J. G. \& Angelo, C. P. (2001). The Chemistry of Isatins: a Review from 1975 to 1999 . J. Braz. Chem. Soc. 12 (3), 273 - 324. DOI: 10.1590/S010350532001000300002.
5. Bergman, J., Lindström, J. O. \& Tilstam, U. (1985). The structure and properties of some indolic constituents in Couroupita guianensis aubl. Tetrahedron. 41 (14), 2879 2881. DOI:10.1016/S0040-4020(01)96609-8.

6. Kapadia, G. J., Shukla, Y. N., Basak, S. P., Sokoloski, E. A. \& Fales, H. M. (1980). The melosatins a novel class of alkaloids from melochia tomentosa. Tetrahedron. 36, 2441 2447. DOI:10.1016/0040-4020(80)80221-3.

7. Hodges, R. J., Ronaldson, W., Taylor, A. \& White, E. P. (1963). Sporidesmins. Part II. The structure of degradation products related to 5-chloro-6,7-dimethoxyisatin. J. Chem. Soc. 5332 - 5336. DOI: 10.1039/JR9630005332.

8. Gulland, J. M., Robinson, R., Scott, J. \& Thornley, S. (1929). 6: 7-Dimethoxyisatin, 5 : 6-methylenedioxyisatin, and the nuclear degradation of 3: 4-methylenedioxyquindoline. J. Chem. Soc. 2924 - 2927. DOI: 10.1039/JR9290002924.

9. Bamoharram, F. F., Heravi, M. M., Roshani, M., Gharib, A. \& Jahangir, M. (2006). A catalytic method for synthesis of $\gamma$-butyrolactone, $\varepsilon$-caprolactone and 2-cumaranone in the presence of Preyssler's anion, $\left[\mathrm{NaP}_{5} \mathrm{~W}_{30} \mathrm{O}_{110}\right]^{14-}$, as a green and reusable catalyst. J. Mol. Catal. 252, 90 - 95. DOI:10.1016/ j.molcata.2006.01.067. 